See discussions, stats, and author profiles for this publication at: https://www.researchgate.net/publication/311536503

Shifting from acquisitive to conservative: the effects of Phoradendron affine (Pohl ex DC.) Engl. \& K. Krause (Santalaceae) infection in leaf morphophysiological traits of a Neotr...

Article in Australian Journal of Botany · November 2016

DOI: $10.1071 / \mathrm{BT} 16177$

3 authors, including:

Marina Corrêa Scalon 


\title{
Shifting from acquisitive to conservative: the effects of Phoradendron affine (Santalaceae) infection in leaf morpho-physiological traits of a Neotropical tree species
}

\author{
Marina Corrêa Scalon ${ }^{\mathrm{A}}$, Sabrina Alves dos Reis ${ }^{\mathrm{B}}$ and Davi Rodrigo Rossatto ${ }^{\mathrm{B}, \mathrm{C}}$ \\ A Departamento de Ecologia, Instituto de Ciências Biológicas, Universidade de Brasília, Caixa Postal 04457, \\ 70904-970, Brasília, DF, Brasil. \\ ${ }^{B}$ Departamento de Biologia, Faculdade de Ciências Agrárias e Veterinárias, Universidade Estadual Paulista, \\ Via de Acesso Professor Paulo Donatto Castellane S/N, Vila Industrial, 14884-900, Jaboticabal, SP, Brasil. \\ ${ }^{\mathrm{C}}$ Corresponding author. Email: drrossatto@gmail.com
}

\begin{abstract}
Mistletoes are parasitic plants that penetrate the host branches through a modified root and connect to their xylem to acquire nutrients and water. Under mistletoe infection, resources that would otherwise be used by the host are stolen by the parasite. Our aim was to compare leaf morpho-physiological traits between healthy uninfected branches and mistletoe-infected branches of a Neotropical tree species (Handroanthus chrysotrichus (Mart. ex DC.) Mattos Bignoniaceae). We also investigated differences between mistletoe and host leaf traits. Morphological (petiole length and thickness, leaf area and thickness, and specific leaf area) and physiological leaf traits (pre-dawn and midday water potential) were measured in 10 individuals infected with the mistletoe Phoradendron affine (Pohl ex DC.) Engl. \& K.Krause (Santalaceae). Mistletoes showed smaller and thicker leaves with lower pre-dawn and midday water potential, suggesting that mistletoes are more profligate water users than the host. Host leaves from infected branches were scleromorphic and showed stronger water-use control (less negative water potential) than host leaves from uninfected branches. Our results indicated that leaves from infected branches shifted to a more conservative resource-use strategy as a response to a water and nutrient imbalance caused by mistletoe infection.
\end{abstract}

Additional keywords: hemiparasite, leaf morphology, leaf traits, leaf water potential, resource use.

Received 1 September 2016, accepted 24 November 2016, published online 10 January 2017

\section{Introduction}

Mistletoes are parasitic plants that attach to the trunk or shoots of trees, establishing a close association with the host xylem tissue to obtain water and mineral resources for their development and survival (Escher et al. 2008). Therefore, because mistletoes essentially depend on water and mineral resources acquired from the host xylem (Calder and Bernhardt 1983; Press and Graves 1995), they need to outcompete their hosts successfully, by displaying more efficient water- and nutrient-acquisition strategies (Scalon and Wright 2015). In a manner similar to that of some herbivores (such as sap-tapping aphids), mistletoes alter resource allocation and compete with the host sinks (Orozco et al. 1990; Meinzer et al. 2004). Mistletoes usually exhibit higher transpiration rates than hosts, to maintain a strong water-potential gradient and convert the mistletoe hydraulic system into a sink, shifting water and nutrients from the host to the mistletoe (Ehleringer et al. 1986; Scalon et al. 2016a). This strategy suggests that the success of an infection relies on the capacity of the hemiparasite to display a set of leaf morphophysiological traits that would favour resource acquisition
(Lüttge et al. 1998; Bowie and Ward 2004), ensuring the flow of the host sap to the mistletoe. Indeed, marked differences between mistletoe and host physiology have been reported. For instance, mistletoes usually show higher transpiration rates and stomatal conductance, but lower carbon assimilation and specific leaf area (Ullmann et al. 1985; Escher et al. 2004; Glatzel and Geils 2009).

Given this set of physiological and morphological adaptations, resources are translocated to the hemiparasite, which could have a detrimental effect on the host leaves (Glatzel 1983; Glatzel and Geils 2009). The amount of nutrients and water reaching the host meristems might be affected, resulting in significant structural and physiological changes in newly formed leaves. Under low resource availability, such as water deficit and nutrient deficiency, plants are expected to invest less in growth and build leaves with traits leading to a more conservative resource use (i.e. sclerophyllous leaves, lower leaf area, lower specific leaf area, and stronger stomatal control; Niinemets 2001; Wright et al. 2004; Rossatto and Kolb 2009). 
Hemiparasite infections may affect individual branches of the host tree, or even the entire host canopy, depending on the relative size of the mistletoe and the host (Kuijt 1969). Mistletoes have been shown to cause changes in host allometry, growth and reproduction (Press and Phoenix 2005), gas exchange and water balance (Meinzer et al. 2004), and even host survival (Reid et al. 1992). Conversely, other studies have found very limited change between infected and non-infected host plants, especially in carbon assimilation and carbon balance (Reblin et al. 2006; Logan et al. 2013). Despite being debated in the literature, morpho-physiological responses of hosts to mistletoe infections remain under-investigated.

Most common hemiparasitic plants belong to the family Santalaceae, which comprises 44 genera and 950 species globally that mainly occur in tropical and subtropical regions. Santalaceae species are classified into root or aerial-shoot hemiparasites, according to where their haustorium (modified root) connects to the host (Judd et al. 2016). The genus Phoradendon (67 species) is the most widely distributed and common hemiparasite genus in Brazil (Arruda et al. 2012). Phoradendron plants are frequently found in many host species from forests and savannas, and are reported to cause significant branch mortality over short time scales (Arruda et al. 2012).

Many recent studies have focused on physiological differences between hemirapasites and host leaves (Bannister and Strong 2001; Scalon et al. 2013, 2016a; Scalon and Wright 2015), but few studies have assessed morpho-physiological differences between leaves of infected and non-infected branches (Arruda et al. 2012; Scalon et al. 2013). The present study had the following two main objectives: (1) to compare resource allocation strategies of mistletoe leaves and healthy host leaves; and (2) to test whether host leaves from infected branches would show distinct morphological and physiological traits compared with leaves of healthy non-infected branches. We hypothesised that mistletoe leaves would show lessconservative water use than host leaves, because they acquire water and nutrients directly from the host, and thus do not need to be conservative. We also expected that host leaves from infected branches would show a more conservative resourceuse strategy (lower leaf area, higher thickness, lower specific leaf area, and better control of water resources) than leaves on healthy, uninfected branches, because of the resource imbalance caused by mistletoes directly retrieving nutrients and water from the infected host branches.

\section{Materials and methods}

\section{Study site}

The present study was undertaken at Faculdade de Ciências Agrárias e Veterinárias, UNESP, Jaboticabal, SP, Brazil, during November 2015 (the wet season). The study site (an Handroanthus sp. grove; see Chaves et al. 2016 for more details) was located at $21^{\circ} 14^{\prime} 39.37^{\prime \prime} \mathrm{S}$ and $48^{\circ} 18^{\prime} 01.60^{\prime \prime} \mathrm{W}$. Average annual precipitation in the study area is $\sim 1420 \mathrm{~mm}$ (historic average for the period 1971-2010), with a marked dry season between June and August.

\section{Studied species and morpho-physiological traits}

We selected 10 adult individuals of the host Handroanthus chrysotrichus (Mart. ex DC.) Mattos (Bignoniaceae) infected by the mistletoe Phoradendron affine (Pohl ex DC.) Engl. and K.Krause (Santalaceae). Handroanthus chrysotrichus is the preferred host species of the mistletoe $P$. affine $(\sim 60 \%$ of $H$. chrysotrichus in parks and urban areas are infected by $P$. affine according to Maruyama et al. 2012). Each sampled tree had only one attached $P$. affine individual, and, for each $H$. chrysotrichus individual, we selected one branch with and one without the presence of the hemiparasite. All individual hosts were similar in size (mean \pm s.d.: $\mathrm{DBH}=16.39 \pm 4.32 \mathrm{~cm})$, and the selected branches were at a similar height (mean \pm s.d.: $4.0 \pm 0.25 \mathrm{~m}$ ). Branches were also exposed to similar irradiance conditions (mean \pm s.d.: infected branch $=1400 \pm 235 \mu \mathrm{mol}$ $\mathrm{m}^{-2} \mathrm{~s}^{-1}$; and uninfected branch $=1389 \pm 325 \mu \mathrm{mol} \mathrm{m}^{-2} \mathrm{~s}^{-1}$ ).

We sampled five morphological and two physiological leaf traits related to nutrient and water use (Pérez-Harguindeguy et al. 2013). For the morphological traits, we measured leaf thickness (LT), leaf area (LA), specific LA (SLA, the ratio between LA and leaf dry weight), petiole length (PL) and petiole thickness (PT). Leaf thickness, LA and SLA are generally related to resource availability, so that high LA and SLA are generally favoured if nutrients and water are not limited, whereas low LA and SLA are common in environments under resource limitation (Wright et al. 2001). Petiole traits (PL and PT) are related to the amount of nutrients available to build the leaves, and are also good indicators of how plants use and capture light (Capuzzo et al. 2012). To understand physiological strategies related to water resources, we measured leaf water potential at pre-dawn $\left(\psi_{\text {pre-dawn }}\right)$ and at midday $\left(\psi_{\text {midday }}\right)$. Values of $\Psi_{\text {pre-dawn }}$ close to zero indicate that plants have recovered their water status during the night and are not under water stress; $\Psi_{\text {midday }}$ values indicate how plants have used water during morning photosynthesis, indicating transpiration rates (Bucci et al. 2005). We also calculated the variation in $\psi$ ( $\Delta \psi: \psi_{\text {midday }}-\psi_{\text {pre-dawn }}$ ), as a proxy for the degree of stress and amount of water available for photosynthesis (Rossatto et al. 2013).

All traits were measured on one fully expanded sun leaf from the mistletoe, and two from the host, one growing in an infected branch and the other on an uninfected branch. Leaf thickness (in mm), PL (in mm) and PT (in mm) were measured using digital callipers (Mitutoyo, 0.001-mm precision). Leaves were scanned (HP Scanjet 200, Hewlett Packard, Brazil) and their LA $\left(\mathrm{cm}^{2}\right)$ was determined using the software Image $\mathrm{J}$ (Abràmoff et al. 2004). Leaves were dried for $72 \mathrm{~h}$ at $70^{\circ} \mathrm{C}$, and weighed to calculate SLA (in $\mathrm{cm}^{2} \mathrm{~g}^{-1}$, the ratio between LA and dry weight). Leaf water potential (in $\mathrm{MPa}$ ) was determined with a Schölander pressure chamber (PMS Model 1505DEXP, PMS Instrument Company, Albany, OR, USA) at predawn ( 0400 hours to 0500 hours) and midday ( 1200 hours to 1300 hours).

\section{Statistical analysis}

We used the software R version 3.0.1 (R Development Core Team 2015) for all statistical analyses. Univariate and multivariate data normality was checked with Shapiro-Wilk tests, which is appropriate for small sample sizes (Quinn and Keough 2002). We used the package mvnormtest (Jarek 2009) for the 
multivariate test. Univariate homoscedasticity was checked using Bartlett's test, and multivariate variance-covariance homogeneity was checked using Box's M test in the 'biotools' package (Silva 2014). We performed a multivariate ANOVA (MANOVA), followed by paired Student's $t$-tests to test for differences in leaf morpho-physiological traits between mistletoes and hosts, and between infected and uninfected branches within the host. We also tested for differences in bivariate relationships between $\log _{10}$-transformed leaf traits by using the software SMATR (Warton et al. 2012). Relationship strength was quantified using correlation $r^{2}$, whereas relationship slopes were described and compared using standardised major-axis
(SMAs) slopes. For all tests, differences were considered significant at $P<0.05$.

\section{Results}

\section{Mistletoe and host leaves}

Mistletoe and host leaves were different for all traits evaluated in the study (MANOVA, $F_{(1,14)}=20.31, P<0.001$ ). Mistletoes showed thicker and smaller leaves, reflected in lower SLA (Figs 1, 2). In addition, mistletoes also showed a higher amplitude in water potential $(\Delta \psi)$ during the day and more
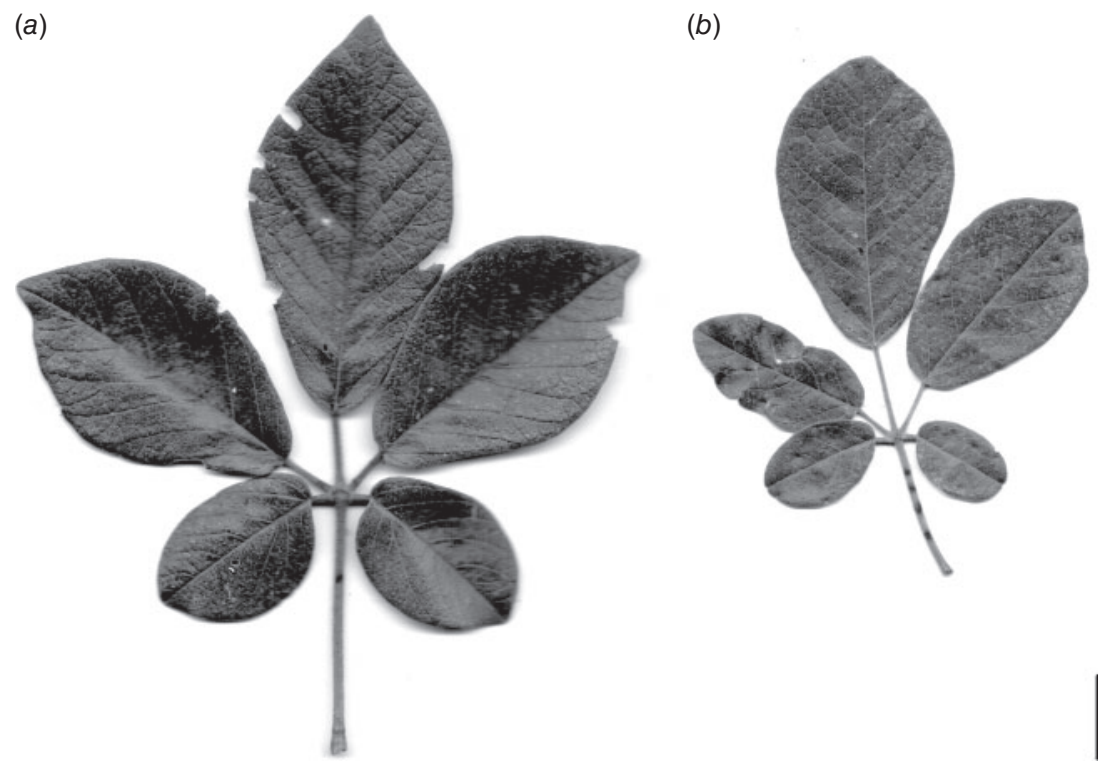

Fig. 1. Leaves from branches of Handroanthus chrysotrichus that are (a) uninfected and $(b)$ infected with the mistletoe Phoradendron affine. Scale bar $=2 \mathrm{~cm}$.
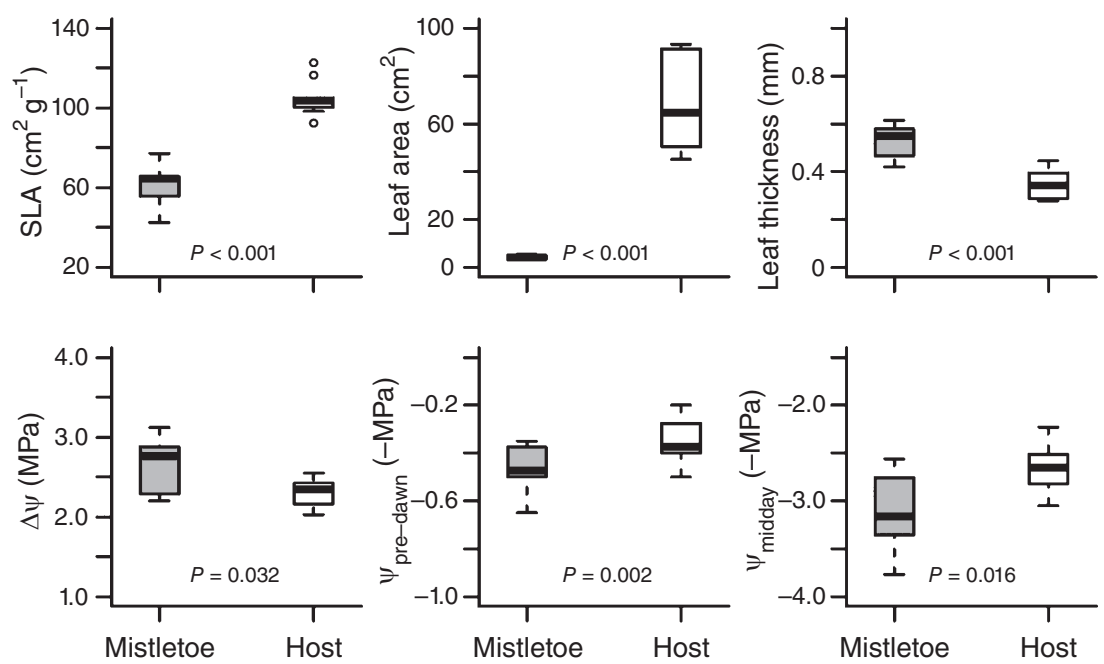

Fig. 2. Pair-wise comparisons between the mistletoe Phoradendron affine and the host Handroanthus chrysotrichus for specific leaf area (SLA), leaf area, leaf thickness, amplitude of daily variation in water potential $(\Delta \psi)$, pre-dawn and midday water potentials ( $\psi_{\text {pre-dawn }}$ and $\psi_{\text {midday }}$ respectively). $P$-values from paired Student's $t$-tests are shown. 
negative pre-dawn and midday water potential than healthy uninfected host leaves (Fig. 2).

\section{Infected and uninfected host leaves}

We found significant differences between infected and uninfected host leaves when considering all traits together (MANOVA, $F_{(1,14)}=6.37, P=0.009$ ). Although there was no difference in LT, parasitised branches showed smaller leaves, which was reflected in a lower SLA (Fig. 3). Leaves from the infected branch also showed shorter and thinner petioles, evidencing another morphological difference in the general structure of the leaves (Fig. 3). Interestingly, leaves from the infected branch showed a lower amplitude in water potential $(\Delta \psi)$ during the day and more negative $\psi_{\text {pre-dawn, but higher }}$ $\psi_{\text {midday }}$ (Fig. 3), suggesting a stronger response to water-deficit stress.

\section{Bivariate relationships}

There was a correlation between SLA and leaf thickness for leaves from healthy non-infected branches $\left(r^{2}=0.42, P=0.023\right.$, SMA slope $(\beta \pm 95 \%$ confidence interval): $-0.50(-0.89,-0.27)$; Fig. 4) and for mistletoe leaves $\left(r^{2}=0.17, P=0.042\right.$, SMA slope ( $\beta \pm 95 \%$ confidence interval): $-1.42(-1.81,-0.71)$; Fig. 4$)$. There was no relationship for leaves from infected branches $\left(r^{2}=0.048, P=0.542\right.$; Fig. 4$)$, which suggests that, for a given LT, LA decreased disproportionally when the branch was parasitised by a mistletoe. Standardised major-axis slopes differed between groups $(P=0.02)$, with mistletoes showing a steeper relationship; i.e. for a 10-fold increase in LT, host leaves from uninfected branches showed only 3.2-fold decrease in SLA, whereas mistletoe leaves showed 26-fold decrease in SLA (Fig. 4).

Similarly, there was a strong correlation between $\psi_{\text {pre-dawn }}$ and $\psi_{\text {midday }}$ in leaves from non-parasitised branches $\left(r^{2}=0.63\right.$, $P=0.019$, SMA slope $(\beta \pm 95 \%$ confidence interval): 2.60 (1.46,
4.65); Fig. 5) and mistletoes $\left(r^{2}=0.46, P=0.045\right.$, SMA slope $(\beta \pm 95 \%$ confidence interval): 4.10 (2.08, 8.04); Fig. 5). In leaves from parasitised branches, $\psi_{\text {pre-dawn }}$ and $\psi_{\text {midday }}$ were uncorrelated $\left(r^{2}=0.14, P=0.350\right.$; Fig. 5). Standardised majoraxis slopes did not differ significantly between the groups ( $P=0.47$, common slope ( $\beta \pm 95 \%$ confidence interval): 2.55 $(1.60,4.01))$, but the relationships differed in elevation (Waldstatistic: $24.67 ; P<0.001$ ), with uninfected branches showing higher $\psi_{\text {midday }}$ for a given $\psi_{\text {pre-dawn }}$. Groups were also shifted along the common axis (Wald-statistic: $6.32 ; P=0.042$ ), with mistletoes showing lower $\psi_{\text {pre-dawn }}$ and $\psi_{\text {midday }}$, but maintaining the same relationship (Fig. 5).

\section{Discussion}

\section{Mistletoe and host differences}

Mistletoe leaves differed from host leaves for all studied traits. The trait differences corroborated our first hypothesis that mistletoe leaves would show less-conservative water use than the host leaves (Fig. 2). However, morphological leaf traits of $P$. affine suggested a conservative resource-use strategy (such as higher LT, and lower LA and SLA), contrasting with the more acquisitive patterns of the host species (higher SLA, and lower LT). The conservative strategy implies that the leaves can live longer, providing better resource storage and recycling in a resource-limited environment (Wright et al. 2004). Despite having access to potentially less costly nutrients that are transferred directly from the host xylem, and not needing to invest in a complex root system, the hemiparasitic life form may impose specific constraints in leaf morphological traits (Stewart and Press 1990). For example, increasing leaf succulence could also be a limitation imposed by the mistletoe life form to keep ion concentration at a tolerable level (Popp et al. 1995). To achieve lower leaf water potential than that of their hosts, mistletoes need to accumulate great quantities of osmolytes and have succulent fleshy leaves with a higher water-storage
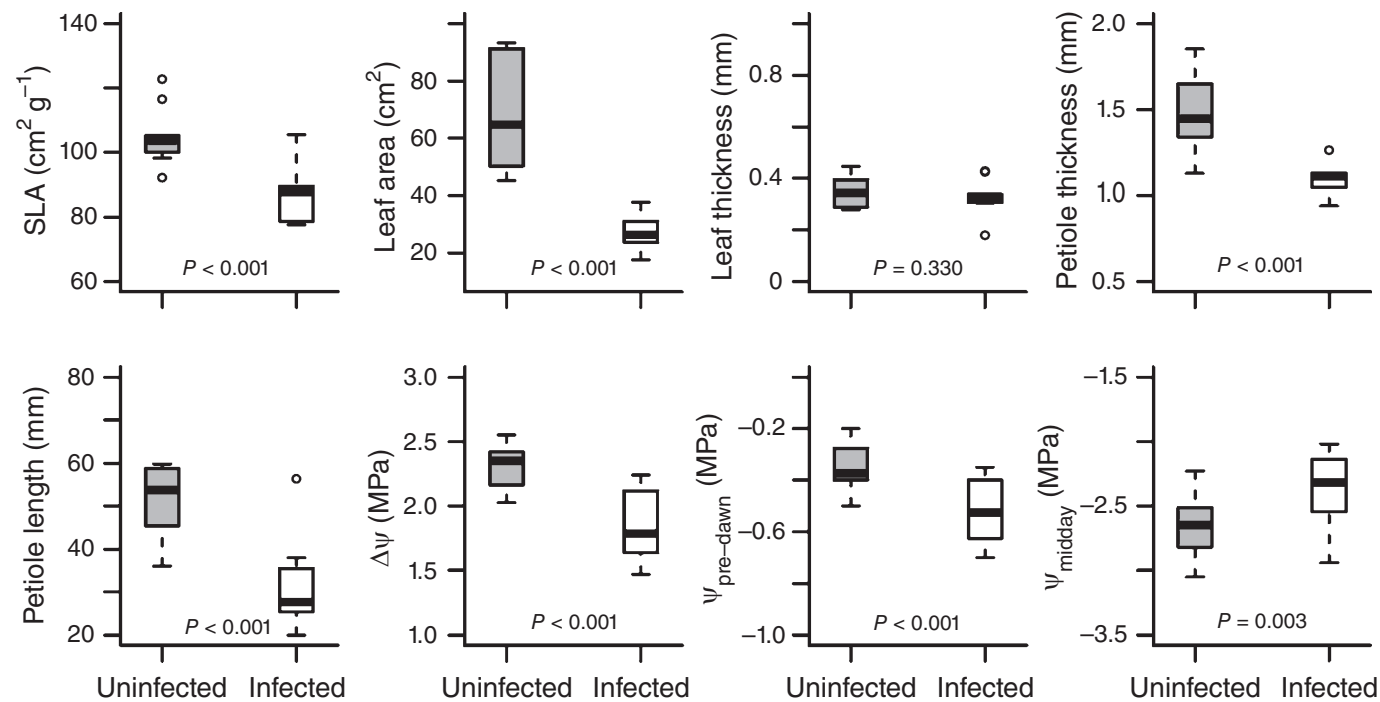

Fig. 3. Pair-wise comparisons between leaves of Handroanthus chrysotrichus from branches uninfected and branches infected with the mistletoe Phoradendron affine for specific leaf area (SLA), leaf area, leaf thickness, petiole thickness, petiole length, amplitude of daily variation in water potential ( $\Delta \psi$ ), pre-dawn and midday water potentials ( $\psi_{\text {pre-dawn }}$ and $\psi_{\text {midday }}$ respectively). $P$-values from paired Student's $t$-tests are shown. 


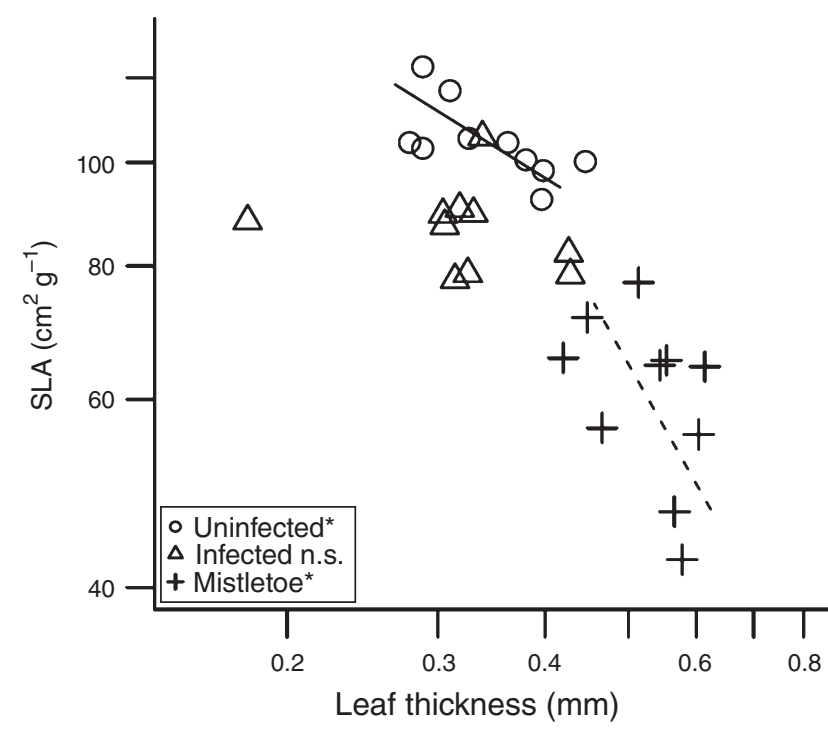

Fig. 4. Standardised major-axis (SMA) relationships between specific leaf area (SLA) and leaf thickness for the mistletoe Phoradendron affine (cross, dashed line, SMA slope $(\beta \pm 95 \%$ confidence interval): $-1.42(-1.81,-0.71)$ ) and its host Handroanthus chrysotrichus from uninfected branches (circles, continuous line SMA slope ( $\beta \pm 95 \%$ confidence interval): $-0.50(-0.89$, $-0.27)$ ) and infected branches (triangles). $* P<0.05$; n.s., not significant. SMA slopes differed between groups $(P=0.02)$.

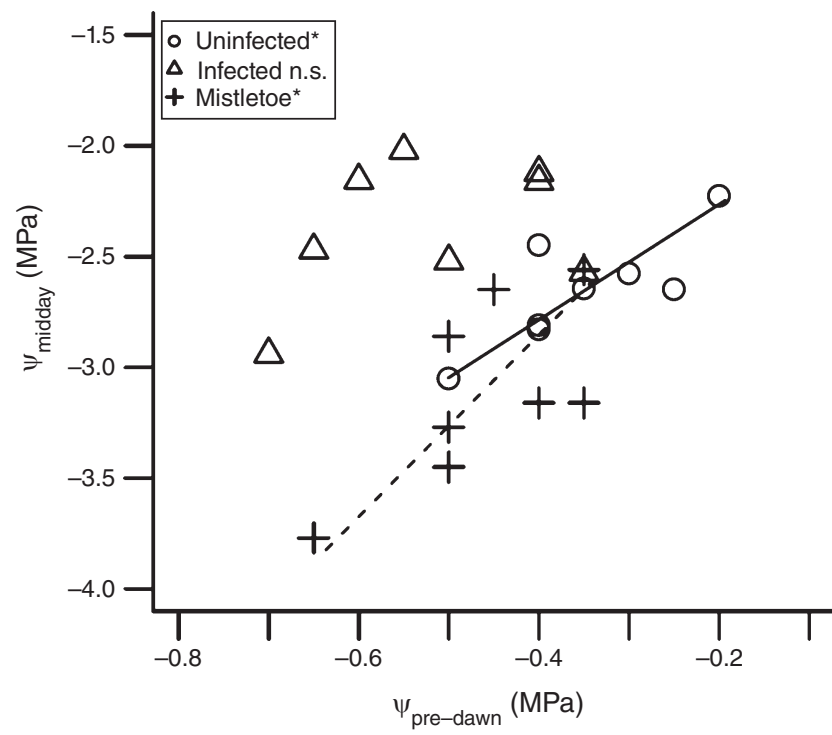

Fig. 5. Standardised major-axis (SMA) relationships between midday water potential $\left(\psi_{\text {midday }}\right)$ and pre-dawn water potential $\left(\psi_{\text {pre-dawn }}\right)$ for the mistletoe Phoradendron affine (cross, dashed line, SMA slope ( $\beta \pm 95 \%$ confidence interval): $4.10(2.08,8.04))$ and its host Handroanthus chrysotrichus from uninfected branches (circles, continuous line, SMA slope $(\beta \pm 95 \%$ confidence interval): $2.60(1.46,4.65))$ and infected branches (triangles). ${ }^{*} P<0.05 ;$ n.s., not significant. Common slope $(\beta \pm 95 \%$ confidence interval): $2.55(1.60,4.01)$.

capacity (Ehleringer et al. 1986; Whittington and Sinclair 1988; Richter and Popp 1992; Popp et al. 1995). Indeed, despite the conservative aspects of the leaf morphology, we found more negative values of both pre-dawn and midday water potential for the mistletoe leaves (Figs 1, 5). Additionally, we found that the mistletoe showed a higher $\Delta \psi$ than its host, which could be a mechanism to increase water flow during the hours of the day where transpiration demand is higher (Scalon et al. 2016a).

Mistletoes from the Loranthaceae family have been shown to be very inefficient in resource use, which is proposed to be a consequence of their unique life form (Scalon and Wright 2015; Scalon et al. 2016b). The patterns found for the Santalaceae mistletoe studied here were similar, suggesting that mistletoe leaf traits could be constrained by the life form, or even by evolutionary aspects, because the group formed by Santalaceae-Opiliaceae is a sister group of Loranthaceae (Der and Nickrent 2008). Mistletoe leaf morphology may have been shaped through natural selection by the pressure to maintain a lower leaf water potential (consequently achieving a higher nutrient uptake via the haustorium), combined with the lack of usual plant sinks (roots and trunk). Evidence for this potential mechanism is strengthened by the differences in the bivariate relationships between traits, where the mistletoe showed slopes different from those of the host (Figs 4, 5).

\section{Differences between infected and uninfected branches}

The genus Handroanthus is typically found in tropical forest environments (Lohmann and Taylor 2014), normally growing under high-water, -light and -nutrient conditions. When uninfected, the combination of traits we found implies a resource-acquisitive strategy. High SLA correlates with high leaf nutrient concentrations and high carbon assimilation rates (Reich et al. 1998; Wright et al. 2004), and larger petioles are related to a better capacity to capture light in the forest canopy (Capuzzo et al. 2012). Indeed, Handroanthus species from forest environments grow faster than their congeneric species living in savanna environments (Rossatto et al. 2009), potentially because they invest in these traits that favour rapid resource acquisition and fast growth.

When infected by mistletoes, host leaves were more in line with a conservative strategy. We found that individual plants were able to show phenotypic plasticity, producing smaller and thicker leaves with strong water control in infected branches (Fig. 3). These differences suggest that infection responses are not only at the whole-plant scale (Watling and Press 2001; Noetzli et al. 2003; Meinzer et al. 2004; Shaw et al. 2005), but can also be detected between branches on the same individual tree. These differences are also evident in the lack of relationships between traits for leaves from infected branches (Figs 4, 5). Specific leaf area generally correlates with LT (Niinemets 2001), as was found for mistletoes and host leaves from uninfected branches (Fig. 4). However, these traits disproportionally decreased in leaves on infected branches, suggesting that parasites are able to change trait relationships in their hosts. The higher LT and the lower SLA suggest that leaves form infected branches were more scleromorphic than were leaves from uninfected branches. Sclerophylly is usually associated with limited nutrient and water availability during foliar expansion (Turner 1994), which supports the idea that the majority of nutrients and water were being preferentially 
translocated to the parasite (Schulze et al. 1984; Glatzel and Geils 2009).

Another interesting finding in our study was the fact that leaves from infected branches had shorter and thinner petioles (Fig. 3). According to Capuzzo et al. (2012), PL and PT are directly related to leaf size, aiding light capture by affecting how leaf blades are displayed in the plant canopy. The host responses indicated that $P$. affine infection was not only affecting leaf size, but also strategies associated with how plants display their leaves to absorb light. It is possible that changes in leaf display in the canopy can affect the carbon balance, possibly leading to carbon starvation if leaf display results in deficiencies in light capture (Sevanto et al. 2014). Some studies have reported that infected branch mortality could be caused by a lack of sufficient nutrient and water resources to maintain their leaves (Press and Phoenix 2005). However, our study suggested that plants can respond to the reduction in resources by building leaves that need less nutrients, water and sunlight to survive. Nevertheless, in the long term, under severe nutrient and water limitation, this capacity for leaf-trait plasticity could become more restricted. If leaves become unable to assimilate the minimum amount of energy necessary for their maintenance, the vegetative part of the infected branch would probably die.

\section{Conclusions}

Leaves from the tropical mistletoe $P$. affine showed conservative morphological traits that are probably phylogenetically conserved, combined with acquisitive physiological traits, which allow for the efficient acquisition of water and nutrients from their hosts. The tropical host $H$. chrysotrichus showed high phenotypic plasticity under infection by mistletoe, with infected branches producing thicker and smaller leaves that shifted to a more conservative resource-use strategy, than leaves from uninfected healthy branches.

\section{Acknowledgements}

We acknowledge the Pró-Reitoria de Pesquisa (PROPE-UNESP) for the scholarship granted to Sabrina A. Reis (PIBIC/UNESP/PROPE-33198). We also thank Fabricius M. C. B. Domingos and Emma F. Gray for proofreading the manuscript.

\section{References}

Abràmoff MD, Magalhães PJ, Ram SJ (2004) Image processing with ImageJ. Biophotonics international 11, 36-43.

Arruda R, Fadini RF, Carvalho LN, Del-Claro K, Mourão FA, Jacobi CM, Teodoro GS, van den Berg E, Caires CS, Dettke GA (2012) Ecology of neotropical mistletoes: an important canopy-dwelling component of Brazilian ecosystems. Acta Botanica Brasílica 26, 264-274.

Bannister P, Strong GL (2001) Carbon and nitrogen isotope ratios, nitrogen content and heterotrophy in New Zealand mistletoes. Oecologia 126, 10-20. doi:10.1007/s004420000495

Bowie M, Ward D (2004) Water and nutrient status of the mistletoe Plicosepalus acaciae parasitic on isolated Negev Desert populations of Acacia raddiana differing in level of mortality. Journal of Arid Environments 56, 487-508. doi:10.1016/S0140-1963(03)00067-3
Bucci SJ, Goldstein G, Meinzer FC, Franco AC, Campanello P, Scholz FG (2005) Mechanisms contributing to seasonal homeostasis of minimum leaf water potential and predawn disequilibrium between soil and plant water potential in Neotropical savanna trees. Trees 19, 296-304. doi:10.1007/s00468-004-0391-2

Calder M, Bernhardt P (1983) 'The biology of mistletoes.' (Academic Press: Sydney)

Capuzzo JP, Rossatto DR, Franco AC (2012) Differences in morphological and physiological leaf characteristics between Tabebuia aurea and T. impetiginosa is related to their typical habitats of occurrence. Acta Botanica Brasílica 26, 519-526. doi:10.1590/S0102-33062012000300002

Chaves CJN, Dyonisio JC, Rossatto DR (2016) Host trait combinations drive abundance and canopy distribution of atmospheric bromeliad assemblages. AoB Plants 8, plw010. doi:10.1093/aobpla/plw010

Der JP, Nickrent DL (2008) A molecular phylogeny of Santalaceae (Santalales). Systematic Botany 33, 107-116. doi:10.1600/036364408783887438

Ehleringer JR, Cook CS, Tieszen LL (1986) Comparative water use and nitrogen relationships in a mistletoe and its host. Oecologia 68, 279-284. doi:10.1007/BF00384800

Escher P, Eiblmeier M, Hetzger I, Rennenberg H (2004) Seasonal and spatial variation of carbohydrates in mistletoes (Viscum album) and the xylem sap of its hosts (Populus $\times$ euamericana and Abies alba). Physiologia Plantarum 120, 212-219. doi:10.1111/j.0031-9317.2004.0230.x

Escher P, Peuke AD, Bannister P, Fink S, Hartung W, Jiang F, Rennenberg H (2008) Transpiration, CO2 assimilation, WUE, and stomatal aperture in leaves of Viscum album (L.): effect of abscisic acid (ABA) in the xylem sap of its host (Populus euamericana). Plant Physiology and Biochemistry 46, 64-70. doi:10.1016/j.plaphy.2007.07.018

Glatzel G (1983) Mineral nutrition and water relations of hemiparasitic mistletoes: a question of partitioning. Experiments with Loranthus europaeus on Quercus petraea and Quercus robur. Oecologia 56, 193-201. doi:10.1007/BF00379691

Glatzel G, Geils BW (2009) Mistletoe ecophysiology: host-parasite interactions. Botany 87, 10-15. doi:10.1139/B08-096

Jarek S (2009) 'Mvnormtest: normality test for multivariate variables. R package.' Available at http://cran.r-project.org/web/packages/ mvnormtest/index.html [verified 8 December 2016]

Judd WS, Campbell CS, Kellogg EA, Stevens PF (2016) 'Plant systematics: a phylogenetic approach.' 4th edn. (Sinauer Associates: Sunderland, MA)

Kuijt J (1969) 'The biology of parasitic flowering plants.' (University of California Press: Berkeley, CA)

Logan BA, Reblin JS, Zonana DM, Dunlavey RF, Hricko CR, Hall AW, Schmiege SC, Butschek RA, Duran KL, Emery RJN, Kurepin LV, Lewis JD, Pharis RP, Phillips NG, Tissue DT (2013) Impact of eastern dwarf mistletoe (Arceuthobium pusillum) on host white spruce (Picea glauca) development, growth and performance across multiple scales. Physiologia Plantarum 147, 502-513. doi:10.1111/j.1399-3054.2012.01681.x

Lohmann LG, Taylor CM (2014) A new generic classification of tribe Bignonieae (Bignoniaceae) 1. Annals of the Missouri Botanical Garden 99, 348-489. doi:10.3417/2003187

Lüttge U, Haridasan M, Fernandes GW, de Mattos EA, Trimborn P, Franco AC, Caldas LS, Ziegler H (1998) Photosynthesis of mistletoes in relation to their hosts at various sites in tropical Brazil. Trees 12, 167-174. doi: $10.1007 / \mathrm{s} 004680050136$

Maruyama PK, Mendes-Rodrigues C, Alves-Silva E, Cunha AF (2012) Parasites in the neighbourhood: interactions of the mistletoe Phoradendron affine (Viscaceae) with its dispersers and hosts in urban areas of Brazil. Flora 207, 768-773. doi:10.1016/j.flora.2012.08.004 
Meinzer F, Woodruff D, Shaw D (2004) Integrated responses of hydraulic architecture, water and carbon relations of western hemlock to dwarf mistletoe infection. Plant, Cell \& Environment 27, 937-946. doi:10.1111/j.1365-3040.2004.01199.x

Niinemets Ü (2001) Global-scale climatic controls of leaf dry mass per area, density, and thickness in trees and shrubs. Ecology 82, 453-469. doi:10.1890/0012-9658(2001)082[0453:GSCCOL]2.0.CO;2

Noetzli KP, Müller B, Sieber TN (2003) Impact of population dynamics of white mistletoe (Viscum album ssp. abietis) on European silver fir (Abies alba). Annals of Forest Science 60, 773-779. doi:10.1051/forest:2003072

Orozco A, Rada F, Azocar A, Goldstein G (1990) How does a mistletoe affect the water, nitrogen and carbon balance of two mangrove ecosystem species? Plant, Cell \& Environment 13, 941-947. doi:10.1111/j.1365-3040.1990.tb01984.x

Pérez-Harguindeguy N, Díaz S, Garnier E, Lavorel S, Poorter H, Jaureguiberry P, Bret-Harte MS, Cornwell WK, Craine JM, Gurvich DE, Urcelay C, Veneklaas EJ, Reich PB, Poorter L, Wright IJ, Ray P, Enrico L, Pausas JG, de Vos AC, Buchmann N, Funes G, Quétier F, Hodgson JG, Thompson K, Morgan HD, ter Steege H, van der Heijden MGA, Sack L, Blonder B, Poschlod P, Vaieretti MV, Conti G, Staver AC, Aquino S, Cornelissen JHC (2013) New handbook for standardised measurement of plant functional traits worldwide. Australian Journal of Botany 61, 167-234. doi:10.1071/BT12225

Popp M, Mensen R, Richter A, Buschmann H, Willert DJ (1995) Solutes and succulence in southern African mistletoes. Trees 9, 303-310. doi:10.1007/BF00202493

Press MC, Graves JD (1995) 'Parasitic plants.' (Chapman \& Hall: London)

Press MC, Phoenix GK (2005) Impacts of parasitic plants on natural communities. New Phytologist 166, 737-751. doi:10.1111/j.1469-8137.2005.01358.x

Quinn GP, Keough MJ (2002) 'Experimental design and data analysis for biologists.' (Cambridge University Press: Cambridge, UK)

R Development Core Team (2015) ' $\mathrm{R}$ : a language and environment for statistical computing.' (R Foundation for Statistical Computing: Vienna)

Reblin JS, Logan BA, Tissue DT (2006) Impact of eastern dwarf mistletoe (Arceuthobium pusillum) infection on the needles of red spruce (Picea rubens) and white spruce (Picea glauca): oxygen exchange, morphology and composition. Tree Physiology 26, 1325-1332. doi:10.1093/treephys/26.10.1325

Reich P, Ellsworth D, Walters M (1998) Leaf structure (specific leaf area) modulates photosynthesis-nitrogen relations: evidence from within and across species and functional groups. Functional Ecology 12, 948-958. doi:10.1046/j.1365-2435.1998.00274.x

Reid N, Smith D, Venables W (1992) Effect of mistletoes (Amyema preissii) on host (Acacia victoriae) survival. Australian Journal of Ecology 17, 219-222. doi:10.1111/j.1442-9993.1992.tb00800.x

Richter A, Popp M (1992) The physiological importance of accumulation of cyclitols in Viscum album L. New Phytologist 121, 431-438. doi:10.1111/j.1469-8137.1992.tb02943.x

Rossatto DR, Kolb RM (2009) An evergreen neotropical savanna tree (Gochnatia polymorpha, Asteraceae) produces different dry-and wetseason leaf types. Australian Journal of Botany 57, 439-443. doi:10.1071/BT09045

Rossatto DR, Hoffmann WA, Franco AC (2009) Differences in growth patterns between co-occurring forest and savanna trees affect the forest-savanna boundary. Functional Ecology 23, 689-698. doi:10.1111/j.1365-2435.2009.01568.x

Rossatto DR, Sternberg LSL, Franco AC (2013) The partitioning of water uptake between growth forms in a Neotropical savanna: do herbs exploit a third water source niche? Plant Biology 15, 84-92. doi:10.1111/j.1438-8677.2012.00618.x
Scalon MC, Wright IJ (2015) A global analysis of water and nitrogen relationships between mistletoes and their hosts: broad-scale tests of old and enduring hypotheses. Functional Ecology 29, 1114-1124. doi:10.1111/1365-2435.12418

Scalon MC, Haridasan M, Franco AC (2013) A comparative study of aluminium and nutrient concentrations in mistletoes on aluminiumaccumulating and non-accumulating hosts. Plant Biology 15, 851-857. doi:10.1111/j.1438-8677.2012.00713.x

Scalon MC, Rossatto DR, Domingos FMCB, Franco AC (2016a) Leaf morphophysiology of a Neotropical mistletoe is shaped by seasonal patterns of host leaf phenology. Oecologia 180, 1103-1112. doi:10.1007/s00442-015-3519-8

Scalon MC, Wright IJ, Franco AC (2016b) To recycle or steal? Nutrient resorption in Australian and Brazilian mistletoes from three lowphosphorus sites. Oikos, in press. doi:10.1111/oik.03455

Schulze ED, Turner N, Glatzel G (1984) Carbon, water and nutrient relations of two mistletoes and their hosts: a hypothesis. Plant, Cell \& Environment 7, 293-299.

Sevanto S, McDowell NG, Dickman LT, Pangle R, Pockman WT (2014) How do trees die? A test of the hydraulic failure and carbon starvation hypotheses. Plant, Cell \& Environment 37, 153-161. doi: $10.1111 /$ pce. 12141

Shaw DC, Chen J, Freeman EA, Braun DM (2005) Spatial and population characteristics of dwarf mistletoe infected trees in an old-growth Douglasfir western hemlock forest. Canadian Journal of Forest Research 35, 990-1001. doi:10.1139/x05-022

Silva, AR (2014) 'Biotools: tools for biometry and applied statistics in agricultural science.' R package version 1.Available at: https://rdrr.io/ cran/biotools/man/biotools-package.html [verified 8 December 2016]

Stewart GR, Press MC (1990) The physiology and biochemistry of parasitic angiosperms. Annual Review of Plant Biology 41, 127-151. doi:10.1146/annurev.pp.41.060190.001015

Turner IM (1994) Sclerophylly: primarily protective? Functional Ecology 8 , 669-675. doi:10.2307/2390225

Ullmann I, Lange O, Ziegler H, Ehleringer J, Schulze ED, Cowan I (1985) Diurnal courses of leaf conductance and transpiration of mistletoes and their hosts in central Australia. Oecologia 67, 577-587. doi:10.1007/BF00790030

Warton DI, Duursma RA, Falster DS, Taskinen S (2012) smatr 3: an R package for estimation and inference about allometric lines. Methods in Ecology and Evolution 3, 257-259. doi:10.1111/j.2041-210X.2011.00153.x

Watling J, Press M (2001) Impacts of infection by parasitic angiosperms on host photosynthesis. Plant Biology 3, 244-250. doi:10.1055/s-2001-15195

Whittington J, Sinclair R (1988) Water relations of the mistletoe, Amyema miquelii, and its host Eucalyptus fasciculosa. Australian Journal of Botany 36, 239-255. doi:10.1071/BT9880239

Wright IJ, Reich PB, Westoby M (2001) Strategy shifts in leaf physiology, structure and nutrient content between species of high-and low-rainfall and high-and low-nutrient habitats. Functional Ecology 15, 423-434. doi:10.1046/j.0269-8463.2001.00542.x

Wright IJ, Reich PB, Westoby M, Ackerly DD, Baruch Z, Bongers F, Cavender-Bares J, Chapin T, Cornelissen JHC, Diemer M, Flexas J, Garnier E, Groom PK, Gulias J, Hikosaka K, Lamont BB, Lee T, Lee W, Lusk C, Midgley JJ, Navas M-L, Niinemets Ü, Oleksyn J, Osada N, Poorter H, Poot P, Prior L, Pyankov VI, Roumet C, Thomas SC, Tjoelker MG, Veneklaas EJ, Villar R (2004) The worldwide leaf economics spectrum. Nature 428, 821-827. doi:10.1038/nature02403

Handling Editor: Stephen Trueman 